\title{
BUDAYA SUNGKEM DESA SAMIRONO DALAM PERSPEKTIF HUKUM TAURAT KE-5: SUATU KAJIAN ETIKA KRISTEN DAN GENERASI MUDA
}

\author{
THE SUNGKEM CULTURE OF SAMIRONO VILLAGE IN \\ THE PERSPECTIVE OF THE 5TH LAW: A STUDY OF \\ CHRISTIAN ETHICS AND YOUTH GENERATION
}

\author{
Gernaida Pakpahan', Anggi Maringan Hasiholan², dan \\ Ibnu Salman ${ }^{3}$ \\ 1,2 Sekolah Tinggi Teologi Bethel Indonesia, Jakarta \\ ${ }^{3}$ Badan Penelitian dan Pengembangan dan Pendidikan dan Pelatihan, \\ Kementerian Agama Republik Indonesia \\ anggimaringan.mia2@gmail.com
}

DOI: 10.31291/jlka.v19.i2.990

Diterima: 15 September 2021; Direvisi: 15 Desember 2021;

Diterbitkan: 31 Desember 2021

\section{ABSTRACT}

Culture and religion are two directions of life that are close to the people of Indonesia. Indonesia is referred to as a religious country and a country rich in local wisdom that regulates how humans should behave. One of the cultures familiar with hospitality and full of moral values in Indonesia is Sungkeman. Sungkeman culture as a noble value must be practiced and preserved by all Indonesian people, especially the younger generation. This principle is in line with Christianity which upholds respect for parents and others as an action that needs to carry out. This study explores the correlation of the 5th Torah law, namely respecting parents, with the Sungkeman culture of Samirono Village, which has implications for how a Christian should live in cultural ethics, especially the younger generation. This paper results from field research in Samirono Village, Central Java. The research approach used is descriptive qualitative with data collection techniques consisting of interviews, observations, and documentation. The results show that Sungkem culture has implementable values according to 


\begin{abstract}
the 5th Torah and Christian ethics that must do every day, not just weddings and ketupat Eid. In particular, the tradition must carry out to the younger generation who have experienced the degradation of Sungkem values due to the times. This research recommends that the internalization of respecting others echo in church services and discipleship classes, especially for the younger generation who have begun exposing themselves to globalization's negative currents.
\end{abstract}

Keywords: Sungkem, Samirono Village, Young Generation, Christian Ethics, 5th Law.

\title{
ABSTRAK
}

Budaya dan agama adalah dua arahan kehidupan yang dekat dengan masyarakat Indonesia. Indonesia disebut sebagai negara beragama sekaligus negara yang kaya akan kearifan lokal yang mengatur bagaimana seharusnya manusia berlaku. Salah satu budaya yang akrab dengan keramahtamahan dan penuh dengan nilai moralitas di Indonesia adalah Sungkeman. Prinsip ini sejalan dengan Kekristenan yang menjunjung penghormatan kepada orang tua dan orang lain sebagai tindakan yang perlu tetap dilaksanakan. Budaya sungkeman sebagai nilai luhur mesti dilakukan dan dilestarikan oleh seluruh masyarakat Indonesia, khususnya generasi muda. Artikel ini bertujuan untuk mengeksplorasi korelasi hukum Taurat ke-5 yaitu menghormati orang tua dengan budaya Sungkeman Desa Samirono yang berimplikasi kepada bagaimana seharusnya seorang Kristen hidup dalam etika budaya, khususnya generasi muda. Tulisan ini merupakan hasil riset lapangan di Desa Samirono, Jawa Tengah. Pendekatan penelitian yang digunakan adalah kualitatif deskriptif dengan teknik pengumpulan datanya terdiri dari wawancara, observasi dan dokumentasi. Hasil penelitian menunjukkan bahwa budaya Sungkem memiliki nilai implementatif sesuai hukum Taurat ke-5 dan etika Kristen yang harus dilakukan setiap hari bukan hanya momen pernikahan dan lebaran ketupat. Khususnya pentradisian harus dilakukan kepada generasi muda yang telah mengalami degradasi nilai Sungkem akibat perkembangan zaman. Riset ini merekomendasikan agar internalisasi nilai-nilai menghormati sesama digemakan dalam ibadah-ibadah dan kelas-kelas pemuridan gereja, terkhusus bagi generasi muda yang sudah mulai terpapar arus globalisasi negatif.

Kata kunci: Sungkem, Desa Samirono, Generasi Muda, Etika Kristen, Hukum Taurat ke-5.

\section{PENDAHULUAN}

Nilai positif yang melekat dengan orang Jawa dalam interaksi sosial adalah menerapkan etika dalam bersikap dengan 
mengedepankan sopan-santun dan tata krama. Tindakan sederhana biasanya diimplementasikan dengan selalu mengucapkan kata "permisi" saat melewati orang-orang yang sedang duduk atau yang berpapasan lewat, meskipun belum mengenal orang tersebut. ${ }^{1}$ Terlihat sederhana, tetapi etika itu adalah ciri khas orang Jawa yang menyebar ke seluruh Nusantara sehingga menjadi kebiasaan baik yang melekat dengan budaya Indonesia. Selain itu, terdapat berbagai budaya lain yang identik dengan suku Jawa, yaitu Sungkem atau Sungkeman. Budaya Sungkem adalah suatu budaya yang terkenal dikalangan masyarakat Indonesia. Hal ini banyak dilakukan dalam acara-acara tertentu; seperti pernikahan, perayaan Idul Fitri, dan lainnya. Kedua budaya ini sedang dalam taraf degradasi secara perlahan karena arus globalisasi yang merebak di seluruh lapisan masyarakat. ${ }^{2}$

Budaya Sungkeman telah menjamur di masyarakat yang dibawa oleh orang Jawa dan tersebar di seluruh Indonesia. Budaya Sungkeman pada dasarnya adalah kearifan lokal atau tradisional masyarakat suku Jawa. Nilai positif yang dihasilkan dari budaya sungkeman banyak ditiru oleh masyarakat yang bukan orang Jawa dan sebagian menerapkannya sebagai suatu kegiatan wajib. ${ }^{3}$ Konteks sekarang, budaya Sungkeman hanya mengikuti tindakan lahiriah atau sebagai sesuatu yang wajib dilakukan dalam acara-acara dan upacara tertentu, tanpa diketahui makna yang terkandung didalamnya. Problem krusialnya nilai-nilai dan filosofi mendalam dari budaya sungkem tidak lagi menjadi sesuatu nilai positif yang harus dikedepankan, tetapi sekedar ritus kebiasaan semata sebagai rangkaian dari berbagai

${ }^{1} \mathrm{Ki}$ Hajar Dewantoro, Bagian II A: Kebudayaan (Yogyakarta: Madjelis Luhur Persatuan Taman Siswa, 1967).

${ }^{2}$ Saiful Bahri, "Implementasi Pendidikan Karakter Dalam Mengatasi Krisis Moral Di," Jurnal Pendidikan Karakter 03, no. 01 (2015): 57-76, https://media.neliti.com/media/publications/67939-ID-implementasipendidikan-karakter-dalam-m.pdf.

${ }^{3}$ Arif Muhammad, "Sungkeman, Aktivitas Wajib Di Hari Lebaran, Warisan Budaya Bangsa Sarat Makna," Kompasiana. 
seremonial ataupun upacara adat. ${ }^{4}$ Sudah praktiknya dalam upacara mulai tidak dilakukan, nilai esensialnya pun tidak dihayati dengan penuh khitmat dan kesakralan di masyarakat.

Upacara adat merupakan suatu sistem kegiatan, tindakan, dan rangkaian yang diatur sedemikian rupa oleh kebiasaan hukum yang berlaku dalam masyarakat tertentu yang berhubungan dengan berbagai peristiwa tetap, yang biasanya terjadi di dalam masyarakat yang bersangkutan. ${ }^{5}$ Mengutip yang disampaikan oleh Geertz bahwa upacara adat di Indonesia syarat dengan simbol yang bermakna. Konsep makna dalam istilah budaya mengacu pada apa yang dibawa oleh budaya. Budaya itu sendiri merupakan simbol yang harus diresapi maknanya. ${ }^{6}$ Simbol yang dimaksud adalah makna dan nilai yang dibungkus dengan praktik atau benda tertentu. Pemaknaan dan penyimbolan ini diulangi berkali-kali sehingga menjadi world view yang dipegang oleh masyarakat tertentu.

Dalam kebudayaan Jawa, nilai-nilai budaya yang telah menjadi cara hidup kemudian menetap dalam tradisi dan adat istiadat yang dipegang teguh dan diwujudkan dengan upacara adat. Simbol yang digunakan untuk mewujudkan kearifan lokal yang ada di masyarakat juga dipatuhi dengan baik dalam rangka mencapai makna dibalik simbol. ${ }^{7}$ Penulis sedang tidak dalam kapasitas untuk melakukan kajian budaya apakah boleh atau tidak adat istiadat dan upacara dengan makna yang tersirat di dalamnya, tetapi lebih pada bagaimana menangkap dan mengelaborasikan prinsip yang terdapat dalam budaya Sungkem.

Budaya Sungkem pada dasarnya adalah bagian dari "agama suku" Kejawen. Kejawen dipahami dan dipercaya adalah ajaran kebatinan yang telah ada sejak orang Jawa ada di dunia.

${ }^{4}$ Afika Fitria Permatasari and Mahendra Wijaya, "Perubahan Perilaku Masyarakat Jawa Dalam Penyelenggaraan Resepsi Pernikahan Di Kota Surakarta," Jurnal Analisa Sosiologi 6, no. 1 (2018): 65-81.

5 Koentjaraningrat, Sejarah Teori Antropologi I (Jakarta: Universitas Indonesia Press, 1987).

${ }^{6}$ C Geertz, Tafsir Kebudayaan (Yogyakarta: Kanisius, 2000).

${ }^{7}$ Septin Lovenia Indrati, "Philosophical Values and Local Wisdom in Java Panggih Traditional Ceremony Language," PAROLE: Journal of Linguistics and Education 7, no. 2 (2018): 93. 
Tidak diketahui kapan datangnya, tetapi isi ajarannya berkaitan dengan filosofi-filosofi Jawa, yang dapat dikatakan sebagai nenek moyang suku Jawa. Jika melihat ajaran yang diberikan, penganut agama suku Kejawen melaksanakan segala kegiatan yang telah diatur dengan baik dan benar. Sebagai contoh mengenai puasa yang mereka lakukan. Agama Islam mengenal puasa pada saat menuju hari kemenangan Idul Fitri (Ramadhan) sebagai ibadah kedua setelah Sholat dalam rukun Islam. ${ }^{8}$ Lain halnya dengan Kekristenan yang memiliki berbagai macam puasa yang dilakukan bukan dengan kewajiban keras melainkan sukarela dengan berbagai tujuan tertentu. ${ }^{9}$ Dalam kepercayaan Kejawen, terbagi atas bermacam-macam puasa, seperti puasa Mutih (dilakukan dengan jalan hanya boleh makan nasi putih, tanpa garam dan lauk pauk atau makanan kecil dan lain-lain, serta minumnya juga air putih), puasa Patigeni (tidak diperkenankan untuk makan, minum dan tidur serta hanya boleh di kamar saja tanpa disinari cahaya lampu), puasa Ngebleng (tidak diperbolehkan makan dan minum, keluar kamar, boleh keluar sekadar tetapi sekadar buang hajat dan boleh tidur tetapi sebentar saja), puasa Ngalong (puasa tidak makan dan minum tetapi boleh tidur sebentar saja dan boleh pergi, puasa Ngrowot (tidak boleh makan nasi dan hanya boleh makan buah-buahan atau sayursayuran saja. Praktik puasa ini dilaksanakan secara ketat tanpa ada cacat sedikitpun. ${ }^{10}$

Nilai menghormati menjadi bagian utama yang meresap dalam budaya Sungkem Jawa ini. Menghormati ditunjukkan dengan wujud sujud kepada orang tua untuk meminta maaf jika melakukan kesalahan atau meminta doa restu ketika hendak mengambil keputusan penting dalam perjalanan hidup seperti

${ }^{8}$ Safria Andy, "Hakikat Puasa Ramadhan Dalam Perspektif Tasawuf (Tafsir Q.S Al-Baqarah: 183)," Jurnal Ibn Abbas (2017): 1-17.

${ }^{9}$ M. Darojat Ariyanto, Abdullah Mahmud, and Tri Yuliana Wijayanti, “Konsep Puasa Dalam Agama Protestan," Suhuf 24, no. 1 (2012): 99-119, https://publikasiilmiah.ums.ac.id/bitstream/handle/11617/3085/2. DAROJAT ARIYANTO.pdf?sequence $=1 \&$ isAllowed=y.

${ }^{10}$ Soesilo and Krisnina Maharani Tandjung, Kejawen: Philosofi Dan Perilaku, 4th ed. (Malang: Yayasan Yusula, 2005). 
menikah dan memilih pekerjaan. Sungkeman kental dengan kehidupan yang harmonis antar sesama manusia dalam unit kecil, yakni keluarga, maupun yang lebih besar, komunitas dan lingkungan. Berdasarkan nilai luhur Sungkeman, artikel ini bertujuan untuk mengeksplorasi pemahaman dan pengamalan masyarakat Desa Samirono, Salatiga, Jawa Tengah mengenai budaya Sungkem di era postmodern. Selanjutnya, pemahaman itu dikaitkan dengan sudut pandang etika kristen dalam hukum Taurat ke-5, yaitu menghormati ayah dan ibu.

Peneliti memilih Desa Samirono sebagai tempat penelitian karena daerahnya yang sedang dalam area abu-abu. Maksud daerah abu-abu adalah, daerah ini tidak dikatakan sebagai desa yang sangat desa dan penuh dengan kepercayaan agama suku, tidak juga daerah yang sudah modern dalam segala segi. Desa Samirono terletak di Salatiga, Jawa Tengah, lebih tepatnya desa yang berada di Kecamatan Getasan, Semarang. Batas-batas wilayah Desa Samirono adalah: batas sebelah Utara adalah Desa Sumogawe; batas sebelah Selatan: Desa Jetak dan Tajuk; batas sebelah Timur: Kelurahan Kumpulrejo wilayah Kota Salatiga; dan batas sebelah Barat: Desa Batur.

Desa Samirono memiliki luas secara keseluruhan sebesar 333,99 ha atau sekitar 5,076\% dari luas Kecamatan Getasan. Penggunaan lahan di Desa Samirono meliputi lahan pertanian, dan non pertanian. Lahan pertanian terdiri dari sawah sebesar 70,00 ha dan bukan sawah sebesar 262,04 ha. Sedangkan lahan non pertanian sebesar 71,95 ha.

Desa Samirono terdiri dari 5 Dusun yaitu, Dusun Kendal, Dusun Ponangan, Dusun Tawang, Dusun Samirono, dan Dusun Watulawang. Jumlah penduduk Desa Samirono adalah 2.296 orang dengan kepala keluarga sebanyak 741 orang. Mata pencaharian sebagian besar penduduk Desa Samirono adalah peternak, petani, home industry, dan karyawan swasta. Mayoritas penduduk Desa Samirono beragama Islam dengan jumlah penduduk sebesar 1.728 orang, Kristen Protestan sebesar 468 orang, dan Buddha sebesar 100 orang. Sedangkan agama Kejawen yang adalah agama asli Jawa tidak tercatat dalam catatan sipil karena dalam KTP mereka biasanya mencantumkan agama Islam. Tingkat pendidikan masyarakat Desa Samirono tahun 2015 
adalah tidak tamat SD sebesar 596 orang, tamat SD sebesar 856 orang, tamat SMP sebesar 297, tamat SMA sebesar 167, tamat DI/ II sebesar 14 orang, tamat DIII/ Akademi sebesar 6 orang, dan tamat DIV/ S1 sebesar 26 orang. ${ }^{11}$

Kehidupan sosial masyarakat Samirono sangat toleran. Wujud toleransi ditunjukkan dengan memberi ruang diskusi terhadap perbedaan agama, bahkan perbedaan pilihan dalam pemilihan kepala Desa (Kades), Bupati, bahkan Presiden. Hal ini karena masyarakat lebih mengutamakan kedamaian dibanding dengan kerusuhan karena mempertahankan kebenaran yang belum tentu benar. Sebagai contoh ketika pemilihan Presiden tahun 2019 yang menyebabkan iklim perpolitikan di Indonesia memanas antara dua kubu pasangan calon kala itu, masyarakat Samirono lebih memilih untuk menyediakan fasilitas kampanye dari kedua pasang calon. Kampanye tidak dilakukan oleh satu tim sukses (timses) pasangan, melainkan keduanya dalam satu panggung bersama. Saling percaya antar warga menjadi budaya luhur yang masih kental dalam kehidupan sehari-hari masyarakat Samirono. Menurut masyarakat Desa Samirono, setidaknya sejak tahun 1900, belum pernah ada kejadian pencurian di rumah warga manapun, padahal pintu rumah terbuka tanpa ada yang menjaga.

Berkaitan dengan budaya Sungkem, secara umum narasumber mengatakan bahwa tradisi Sungkem masih tetap dilangsungkan sampai saat ini. Tradisi ini telah ada dari nenek moyang masyarakat Jawa dan terus dilaksanakan secara turun temurun. Desa Samirono mayoritas dihuni oleh mayoritas Muslim, kemudian Kristen, sebagian kecil saja yang masih menganut kepercayaan Kejawen. Ketiga aliran keagamaan ini tidaklah sama sekali membuang budaya Sungkem dalam momen-momen tertentu. Hal ini dikarenakan pemahaman yang mendalam bahwa budaya Sungkem memiliki nilai yang positif. Nilai ini diadopsi secara penuh oleh ketiga agama di atas, tetapi dalam hal kesakralan

11 Pemerintah Daerah Kabupaten Semarang, "Desa Samirono," Pemerintah Daerah Kabupaten Semarang, 2019, https:/getasan. semarangkab.go.id/Desa-samirono/. 
pelaksanaan, budaya Kejawen memegang teguh nilai-nilai dan peraturan dalam melakukan suatu tindakan dan sakramen Kejawen.

Berdasarkan wawancara yang dilakukan dengan perwakilan masyarakat Samirono ditemukan ada beberapa bagian yang berkaitan dengan budaya Sungkem, diantaranya: praktik budaya Sungkem dilaksanakan, jenis-jenis Sungkeman, yaitu Sungkeman saat lebaran dan pernikahan, pandangan generasi muda Jawa terhadap budaya Sungkem, dan tentunya bagaimana Kristen di Desa Samirono memandang budaya ini terkait dengan menghormati orang tua.

Nilai positif dari budaya Sungkem dan bagaimana masyarakat Desa Samirono dalam kemajemukannya tetap berperan dalam menjaga harmonisasi sosial-budaya-agama yang terbuka dan tinggi. Artikel ini hendak memotret bagaimana budaya Sungkem Desa Samirono dipandang dari etika Kristen hukum Taurat ke-5 mengenai menghormati ayah dan ibu. Artikel ini juga hendak mengeksplore pandangan generasi muda Desa Samirono terhadap budaya Sungkem di era globalisasi saat ini.

Penelitian mengenai Sungkem pernah dilakukan oleh Oktafia yang memotret tradisi Sungkem Trompak di Desa Pogalan Kabupaten Magelang yang dikaitkan dengan tindakan konservasi lingkungan. Oktafia mengaitkan ini karena dalam Sungkem Trompak terdapat nilai kebersamaan antar sesama manusia dan sesama alam yang berimplikasi kepada tanggungjawab menjaga alam. ${ }^{12}$ Sedangkan Qudus menelusuri budaya Sungkem dalam kaitannya dengan makna simboliknya dalam pernikahan di Kelurahan Lumpur, Kecamatan Gresik. Hasil penelitian menunjukkan bahwa Sungkem adalah bagian wajib dalam prosesi pernikahan yang berarti tawadu terhadap orang tua. ${ }^{13}$ Dari dua penelitian ini, peneliti setuju dengan gagasan dan

12 Lailatul Hanik Wahyu Oktafia, "Kajian Etnografi Tradisi Sungkem Trompak Di Desa Pogalan Kabupaten Magelang (Kearifan Lokal Dan Konservasi Lingkungan)" (Universitas Islam Negeri Walisongo Semarang, 2018).

13 Achmad Zubair Abdul Qudus, "Kemanten Jadur (Studi Etnografi Tentang Makna Simbolik Dalam Prosesi Perkawinan Di Kelurahan Lumpur, 
konsep yang dibangun oleh kedua penulis, namun yang menjadi kebaruan dari penelitian ini adalah bagaimana Kekristenan mengaitkan antara budaya Sungkem yang berasal dari kepercayaan Kejawen dalam tindak-tanduk hidup jemaat, khususnya dalam menerapkan hukum Taurat ke-5 mengenai menghormati orang tua. Selain itu, peneliti juga hendak memotret bagaimana anak muda memandang kebudayaan ini sebagai prinsip dan nilai budaya.

Metode yang digunakan dalam artikel ini adalah kualitatif deskriptif ${ }^{14}$ dengan analisis etika Kristen dari sudut pandang hukum Taurat ke-5 tentang menghormati ayah dan ibu. Proses penelitian dilakukan di Desa Samirono pada bulan Juni 2019 Mei 2020 dengan teknik pengumpulan data menggunakan triangulasi data, yaitu wawancara secara tidak terstruktur secara tatap muka dan tatap maya, ${ }^{15}$ lalu dokumentasi pelaksanaan dan observasi secara langsung dan online.

Prosedur penelitian dimulai dengan mengungkapkan pemahaman masyarakat Desa Samirono dengan mewawancarai informan kunci seperti masyarakat umum, orang tua, orang muda, perwakilan kepala Desa, dan para pemuka agama. Selanjutnya pandangan masyarakat Desa Samirono tersebut dikaji dengan literatur teori yang membahas perspektif etika kristen dari hukum Taurat ke-5. Analisis dilakukan untuk merefleksikan keterkaitan budaya Sungkem dengan hukum Taurat ke-5. Sebagai implementasi kepada pelestariannya, analisis budaya Sungkem dan hukum Taurat ke-5 dikaitkan dengan spiritualitas generasi muda dalam mengamalkannya.

\section{HASIL DAN PEMBAHASAN}

\section{A. Praktik Sungkeman Desa Samirono}

Kecamatan Gresik, Kabupaten Gresik)," AntroUnairdotNet 2, no. 1 (2013): 134-144.

14 Sugiyono, Metode Penelitian Kualitatif Dan $R$ and D, Bandung: Alfabeta (Alfabeta, 2015).

15 Hamid Patilima, Metode Penelitian Kualitatif, 6th ed. (Bandung: Alfabeta, 2016). 
Secara umum masyarakat Samirono memahami Sungkeman sebagai budaya turun temurun yang wajib dilaksanakan dan dipelihara. Hal ini diajarkan supaya tidak terputus oleh satu generasi, dan supaya kesakralan dalam setiap praktiknya dapat dihayati. Budaya Sungkem dilakukan oleh anak kepada orang tuanya, atau yang lebih muda kepada yang lebih tua. Praktiknya dilakukan dengan cara orangtua duduk di bangku, lebih tinggi daripada anaknya, sebagai wujud pemberian hormat dari semua anak-anaknya. Sedangkan anaknya atau yang muda bersikap duduk atau sujud di depan orang tuanya. Sedangkan yang lebih muda mengambil tangan yang tua dan menaruhkannya di tengah jidat atau mencium tangan orang yang lebih tua/orang tua terkait, kemudian dilanjutkan dengan meminta maaf sambil saling tangis-menangis. Beberapa meresapi sungkeman dengan sangat dalam sampai berpelukan antara keduanya. ${ }^{16}$

Selain praktik di atas, pada masa kini juga terdapat praktik Sungkeman lain yang dapat dilakukan. Menurut Bu Mukiem, Istri dari Kepala Desa Samirono ${ }^{17}$ mengatakan bahwa cara lain melakukan Sungkem adalah dengan duduk bersebelahan di bang$\mathrm{ku}$, posisinya sejajar di antara keduanya, baik yang meminta Sungkem dan juga yang memberikan Sungkem. Hal ini biasanya dilakukan karena yang melakukan Sungkeman adalah sama-sama orang yang telah lanjut usia, walaupun berbeda usia.

Praktik sungkeman yang sangat sakral dilakukan adalah dengan mencium sampai ke kaki orang tuanya, khususnya kepada seorang ibu. Hal ini karena pandangan yang dianut selama ini menyatakan bahwa "Surga ada di bawah telapak kaki ibu." Ibu Mukiem menjelaskan bahwa seorang ibu telah susah payah dalam kesakitan mengandung kurang lebih 9 bulan, maka saat Sungkeman, ucapan dan tindakan terima kasih akan diberikan kepada seorang ibu lebih "dalam" dibanding kepada seorang bapak. Pandangan umum ini tidak menjadi pandangan umum

${ }^{16}$ Fatkhur Rohman, "Makna Filosofi Tradisi Upacara Perkawinan Adat Jawa Kraton Surakarta Dan Yogyakarta (Studi Komparasi)" (Universitas Negeri Islam Walisongo, 2015).

${ }^{17}$ Wawancara dilakukan pada Jumat, 21 Juni 2019 di rumah Kepala Desa 
masyarakat Samirono. Sebab menurut Mbah Wiro, salah satu masyarakat Desa Samirono ${ }^{18}$ yang telah berusia 78 dan biasa menerima Sungkem dari anak-anak, cucu, dan buyutnya dalam perayaan Idul Fitri menyatakan bahwa dirinya menerima ucapan maaf dan terima kasih lebih "dalam" daripada istrinya. Perlakuan ini didapatkan karena Mbah Wiro yang terus mencari makan untuk anak-anaknya walaupun usianya sudah tua.

Uraian di atas secara tidak langsung menegaskan bahwa praktik budaya sungkeman di Desa Samirono merupakan pandangan umum yang praktekkan sesuai dengan kedalaman makna dari budaya Sungkem sebagai implementasi nilai positif yang telah diberikan oleh orang tuanya.

\section{B. Jenis-Jenis dan Makna Sungkeman Desa Samirono}

Bagian ini menjelaskan makna dari praktik yang dilakukan dalam budaya Sungkeman di Desa Samirono. Terdapat penggabungan antara jenis-jenis dan makna dari Sungkeman dikarenakan setiap jenis memiliki makna masing-masing. Berikut merupakan dua jenis Sungkeman yang dilakukan oleh masyarakat Desa Samirono:

\section{Sungkeman Pernikahan}

Sungkeman pada saat pernikahan tidak dapat dipisahkan dari budaya Jawa. Dimanapun mereka berada, Sungkeman pasti ada saat pernikahan dilakukan. ${ }^{19}$ Praktik yang dilakukan sama dengan penjelasan di atas, yaitu dengan pasangan mempelai yang duduk sujud kepada kedua orang tua masing-masing mempelai. Biasanya, dimulai dari orang tua wanita, lalu kepada orang tua laki-laki. Sungkeman selalu diidentikan dengan prosesi yang paling mengharukan dalam acara pernikahan. Haru yang mengalir dalam Sungkeman itu dikarenakan makna dan simbol yang terdapat di dalamnya. Pengantin perempuan dan orang tua pengantin biasanya akan menangis saat menjalani proses ini karena ini

${ }^{18}$ Wawancara dilakukan pada Rabu, 19 Juni 2019 di rumah Mba Wiro

19 Suwarna Pringgawidagda, Tata Upacara Dan Wicara Pengantin Gaya Yogyakarta (Yogyakarta: Kanisius, 2011). 
merupakan proses dimana pengantin meminta maaf dan meminta izin kepada orang tua untuk menikah.

Makna utama dari Sungkeman pernikahan adalah meminta restu untuk membangun keluarga yang baru. Restu dari orang tua ini menjadi syarat penting untuk menerima berkat dari Tuhan. Hal ini tidak bisa terlepas dari pandangan yang menyatakan bahwa restu orang tua adalah restu Tuhan. Jika orang tua menyetujui maka Tuhan juga menyetujui hubungan atau ikatan keluarga yang dibangun. Restu orang tua harus menjadi dasar untuk menjalin hubungan, bukan hanya karena cinta semata. Hal ini yang menyebabkan masyarakat Jawa Kuno setuju dengan pernikahan atas dasar perjodohan.

Sebagaimana ditekankan oleh Ibu Wasilan, salah satu jemaat GBI Samirono ${ }^{20}$ yang menikah karena dijodohkan oleh orang tuanya. Ibu Wasilan mengatakan bahwa "saya mau-mau saja, yang penting orang tua senang dan merestui." Karena restu orang tua yang dikejar oleh pasangan yang ingin menikah, maka momen ini sangat mengharukan dalam prosesi pernikahan.

Makna kedua sungkeman dalam prosesi pernikahan adalah untuk mengucapkan terima kasih kepada orang tua yang telah membesarkan pasangan mempelai, baik perempuan maupun lakilaki dari kecil. Hal ini setidaknya disampaikan oleh Pdt. Timotius Turmudi, Gembala Sidang GBI Samirono. ${ }^{21}$ Lebih jauh beliau mengatakan bahwa ucapan terima kasih ini biasanya disampaikan saat kedua mempelai memeluk orang tuanya sambil menangis. Lalu membisikkan ke telinga orang tuanya dengan berkata "terima kasih bu/pak sudah membesarkan aku sampai saat ini." Atau "terima kasih atas apa yang telah diberikan selama ini." Ibu Umi ${ }^{22}$ menegaskan ini dan melakukannya saat dia menikah. Praktik ini dilakukan oleh Pdt. Timotius ketika melaksanakan pemberkatan nikah anak dari Mba Wasilan, Mas Yudhi Wahyu yang menikah pada 17 Januari 2020.

\footnotetext{
${ }^{20}$ Wawancara dilakukan pada Minggu 16 Juni 2019 Rumah Mbah Putri Wasilan di Dusun Samirono

${ }^{21}$ Wawancara dilakukan pada Rabu, 19 Juni 2019 di rumah Timotius Turmudi, Dusun Samirono

${ }^{22}$ Ibu Umi adalah jemaat GBI Samirono
} 

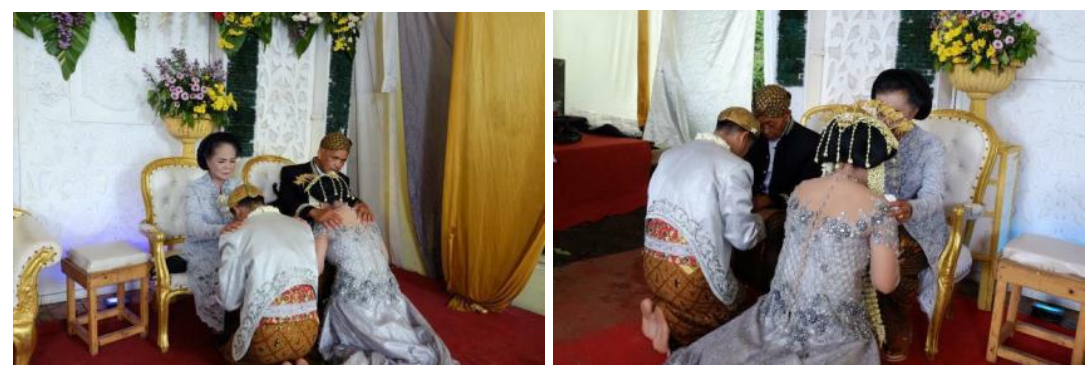

Sumber: Dokumen pribadi keluarga Mba Wasilan, 2020.

\section{Gambar 1.}

\section{Sungkeman pernikahan GBI Samirono}

Makna ketiga dari budaya Sungkem dalam pernikahan yang membuat begitu mengharukan adalah karena kedua mempelai akan meninggalkan rumah orang tuanya, atau orang tuanya melepaskan anaknya. Keharuan ini yang menjadi kesedihan diantara keduanya, baik anak maupun orang tua. Orang tua yang selama ini telah mengurusi anak tentunya sangat sayang dan tidak ingin berpisah dengan anaknya dan bersiap untuk hidup mandiri. Bagian ini pasti dialami oleh orang tua dan anak yang menikah. Proses kemandirian anak juga menimbulkan kesedihan tersendiri bagi seorang ibu, bahkan Ibu Wasilan sampai membangun rumah anaknya yang sudah menikah di samping rumahnya. Informan rela menjual sebagian ladangnya untuk membangun rumah anaknya supaya tidak terpisah jauh dengan dirinya. Tetapi tidak semua orang dapat melakukan ini, dan tidak semua anak yang ingin diperlakukan seperti ini. Atas hal-hal tersebut momen Sungkeman dianggap sebagai sahnya berpisah antara anak dan orangtua.

Makna keempat yang juga didapatkan nantinya juga terdapat dalam Sungkeman lebaran adalah sebagai permintaan maaf. Minta maaf dianggap sebagai makna general yang ada dalam seluruh Sungkem. Hal ini ditegaskan oleh Ibu Mukiem, Istri dari kepala Desa Samirono yang menyamakan bahwa esensi terdalam dari Sungkem adalah untuk tujuan meminta maaf dari orang tua terhadap kesalahan-kesalahan yang dilakukan selama ini. Bahkan Bapak Ratno, Masyarakat Muslim di Desa 
Samirono ${ }^{23}$ dengan tegas mengatakan bahwa alasan melakukan Sungkem adalah untuk minta maaf, tidak ada makna lain selain itu.

\section{Sungkeman Idul Fitri}

Budaya Sungkem yang identik dengan suku Jawa akan sangat mudah ditemui saat perayaan Idul Fitri. Perayaan Idul Fitri bagi orang Jawa disebut dengan Lebaran. Hal ini selalu disebut oleh Pak Ratno, Mas Anton, bahkan Pdt. Timotius Turmudi dalam wawancara yang dilakukan oleh penulis. Sedangkan menurut Mba Wiro, masyarakat Desa Samirono menyebut hari Raya Idul Fitri dengan panggilan hari raya Boto. Namun dibalik semua itu, terdapat sebutan yang paling melekat dengan budaya Jawa adalah Lebaran Ketupat. Lebaran ketupat murni berasal dari tanah Jawa, sejak pemerintahan Paku Boewono IV. Sebuah kearifan lokal yang hanya dilakukan di Indonesia. Lebaran ketupat juga dinamai dengan istilah Badha Kupat. Lebaran ketupat dilaksanakan tepat pada hari ketujuh pada bulan Syawal. ${ }^{24}$

Pada momen lebaran ini, selama satu minggu masyarakat Dusun Samirono saling berkunjung kerumah-rumah tetangga untuk bersama-sama merayakan hari raya Idul Fitri. Menurut beberapa narasumber yang penulis temui di lapangan, seperti; Pak Ratno, masyarakat Muslim Dusun Samirono, Mas Anton, Jemaat GBI Samirono, dan Mba Wiro mengatakan bahwa baik masyarakat Samirono yang Islam ataupun Kristen ikut bersamasama merayakan hari raya Idul Fitri ini. Hal ini dapat dilihat dari banyaknya makanan-makanan ringan dalam toples-toples kaca yang disajikan untuk menyambut kalau ada tetangga yang ingin berkunjung atau silaturahmi. Selain itu juga sebagai rasa saling menghargai satu dengan yang lain. Tim peneliti sendiri hadir menemui masyarakat pada bulan 15-22 Juni 2019, yaitu 2 minggu setelah lebaran ketupat. Karena itu, tim peneliti disambut

${ }^{23}$ Wawancara dilakukan pada Rabu 19 Juni 2019 di rumah Pak Ratno

24 Muh Arif and Yandu Lasantu Melki, "Nilai Pendidikan Dalam Tradisi Lebaran Ketupat Masyarakat Suku Jawa Tondano Di Gorontalo," Madani 1, no. 2 (2019): 144-159. 
dengan hangat oleh masyarakat dengan memberikan makananmakanan ringan yang informan katakan sebagai sisa lebaran 2 minggu lalu.

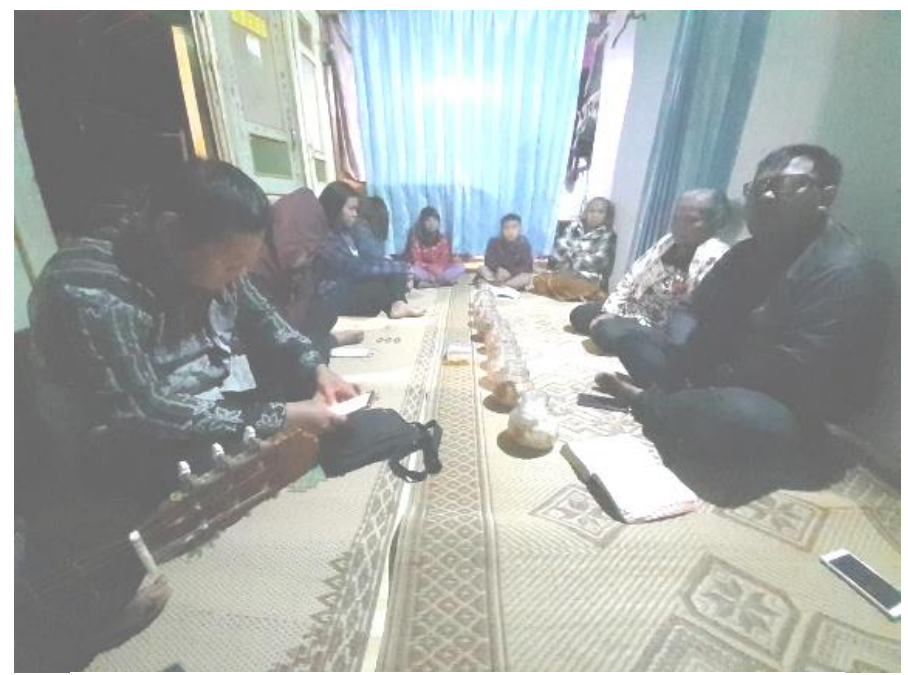

Sumber: Dokumentasi penelitian Desa Samirono. 2019.

Gambar 2.

Idul Fitri bagi Semua Agama di Desa Samirono

Mayoritas seluruh masyarakat Desa Samirono pasti akan keluar rumah setelah melakukan Sholat Ied di Masjid. Keluar rumah yang penulis maksud adalah ke rumah-rumah sanak saudara, baik saudara dekat maupun jauh, dan juga warga yang lainnya. Namun sebelum keluar rumah, biasanya keluarga besar yang ada di rumah akan berkumpul dahulu di ruang tamu untuk melakukan Sungkem. Sungkem dilakukan dengan cara bergantigantian antara ditengah keluarga. Budaya sungkeman dilakukan oleh orang yang sudah berumah tangga, dewasa, bahkan sampai anak kecil. Budaya ini dilakukan turun-temurun sampai saat ini dikarenakan terkandung makna yang luhur.

Makna terdalam dari tradisi Sungkem pada saat lebaran adalah untuk meminta maaf atau saling bermaaf-maafan satu dengan yang lain. Hal ini secara tegas disampaikan oleh Ibu Mukiem dan Mba Wiro yang menyatakan bahwa tujuan satu- 
satunya dari Sungkeman adalah untuk meminta maaf, dan saling bermaaf-maafan. Tidak dapat dipungkiri bahwa dalam hubungan sosial sehari-hari, pasti terdapat kesalahan yang dilakukan. Kesalahan ini dapat disengaja maupun tidak sengaja, atau bisa saja karena kesalahpahaman yang dilakukan dalam bermasyarakat. Moment lebaran dijadikan oleh masyarakat Desa Samirono untuk kembali membangun harmonisasi dan kerukunan yang selama ini dijaga.

\section{Pandangan Generasi Muda terhadap Budaya Sungkem di Desa Samirono}

Budaya Sungkem adalah tradisi baik dan luhur dari nenek moyang orang Jawa yang diajarkan secara turun-temurun kepada anak dan cucunya. Selain maknanya yang dalam, terdapat juga nilai kesakralan yang tinggi di dalamnya. Oleh karenanya, terdapat peraturan-peraturan yang harus diikuti dengan benar dalam pelaksanaanya. Dimulai dari cara jalan menuju orang tua yang disungkemi, cara duduk, cara menyalim tangan orang tua, sampai kepada kata-kata yang disampaikan. Kebiasaan ini masih kental terjaga di antara masyarakat Desa Samirono yang masih memegang kepercayaan Kejawen. Sulit bagi penulis menemukan masyarakat yang benar-benar memegang budaya Kejawen, hal ini karena dalam identitas kependudukannya, mereka mencantumkan agama Islam. Mereka inilah yang disebut dengan "Islam Abangan." Islam Abangan adalah Islam Jawa yang mempraktikkan Islam dalam versi yang lebih sinkretisme dengan adat Jawa. Biasanya yang memegang aliran ini ikut dalam aliran Islam Nahdlatul Ulama (NU) yang terkenal dengan sebutan Islam Moderat. ${ }^{25}$

Pada zaman ini, baik di perkotaan maupun pedesaan sudah mengalami perubahan dalam tatanan masyarakat karena kuatnya arus globalisasi. Hal ini ditandainya dengan perkembangan teknologi yang sangat pesat, jaringan internet yang merata, dan

${ }^{25}$ Adib Fathoni, "Santri Dan Abangan Dalam Kehidupan Keagamaan Orang Jawa," Jurnal At-Taqaddum 4, no. 1 (2012): 101-112. 
informasi yang cepat diakses. ${ }^{26}$ Adanya globalisasi menimbulkan berbagai masalah dalam eksistensi budaya daerah sehingga terjadi degradasi nilai budaya. Pemahaman ini penulis jelaskan karena kebudayaan selalu berkaitan dengan nilai-nilai luhur di dalamnya. Sekecil apapun budaya yang dianut dan menjadi pedoman sebuah masyarakat pasti mengandung makna yang dapat mengatur kehidupan bermasyarakat dengan harmonis. Pemahaman ini tidak seharusnya dipandang sebagai penolakan terhadap kuatnya arus globalisasi. Sebab globalisasi tidak selamanya salah dan merugikan. ${ }^{27}$ Justru globalisasi ini dapat dimanfaatkan untuk kemajuan suatu budaya, terutama budaya-budaya bangsa Indonesia yang beraneka ragam.

Generasi muda seharusnya melihat kemajuan teknologi sebagai sesuatu yang menguntungkan dalam segala segi kehidupan, termasuk dalam mengembangkan nilai-nilai luhur budaya Bangsa, dalam hal ini budaya Sungkem yang menjadi ciri khas budaya Jawa. Namun fakta sebaliknya terjadi kepada generasi muda Desa Samirono. Terjadi degradasi pemahaman terhadap nilai budaya diantara mayoritas anak mudanya. Hal disebabkan karena banyaknya pemuda yang merantau ke kota-kota besar seperti Jakarta, Surabaya, Bandung untuk melanjutkan studi Strata 1 (S1) atau juga mendapatkan pekerjaan di kota-kota besar. Karena lama merantau maka nilai yang dipelihara selama ini tidak diresapi dengan kekhusyukan dan penghayatan. Kehidupan dalam perantauan dihabiskan dengan kegiatan-kegiatan kota yang sibuk dengan diri masing-masing untuk mencapai target yang telah ditetapkan. Sebagai mahasiswa/i ingin supaya semua mata kuliah yang ditempuhnya berhasil dan lulus tepat waktu. Sedangkan yang bekerja ingin supaya tanggung jawab yang diberikan sebagai beban pekerjaan dapat diselesaikan dengan baik. Waktu yang habis dengan kegiatan-kegiatan diatas mem-

${ }^{26}$ Tracy Francis and Fernanda Hoefel, “True Gen”: Generation Z and Its Implications for Companies, McKinsey \& Company, 2018.

${ }^{27}$ A M Hasiholan Tambunan and Andreas Budi Setyobekti, "Ekstraksi Pemahaman Cyprianus Tentang Extra Ecclesiam Nulla Salus Bagi Gereja Pentakosta Di Era Postmodern," KHARISMATA: Jurnal Teologi Pantekosta 4, no. 1 (2021): 28-42. 
buat kurangnya kesempatan untuk memperdalam makna luhur budaya Sungkem.

Merantau di kota-kota besar di luar Jawa Tengah pasti akan mengalami degradasi nilai ini. Hal ini yang disampaikan oleh Mas Joko anak dari kepada Desa Samirono. ${ }^{28}$ Narasumber mengatakan bahwa budaya Sungkem yang masih kental dan syarat dengan nilai kesakralan biasanya terjadi di daerah Jawa Tengah, seperti Solo dan Salatiga. Sedangkan di luar itu tidak diajarkan secara intensif. Oleh karena itu, anak muda yang merantau keluar Jawa Tengah lebih bersifat formalitas ketika melakukan Sungkem. Formalitas karena hal ini menjadi budaya turun temurun dan ada rasa "tidak enakan" atau disebut pekewuh. Jika tidak ikut dalam sungkeman takut dianggap tidak menghormati budaya. Mas Joko mengatakan bahwa pada masa ini anak muda hanya formalitas dalam melaksanakan Sungkeman karena dasar tidak lagi mengharukan saat pelaksanaanya. Hal ini ditegaskan juga oleh ibu Umi, Jemaat GBI Samirono yang melihat budaya Sungkem saat lebaran atau Natal lebih kepada budaya saling menghormati saja antar masyarakat. "Karena dia berkunjung ke rumah saya, yah saya juga gantian berkunjung ke rumah dia" adalah penekanan yang diberikan oleh ibu Umi.

\section{Pandangan Masyarakat Kristen Desa Samirono terhadap Budaya Sungkem}

Kristen adalah agama Samawi yang sama dengan agama Islam dan Yahudi. Dikatakan Samawi karena diturunkan dari Allah secara langsung kepada manusia. ${ }^{29}$ Meskipun demikian, tetap memakai budaya manusia sebagai sarana penyampaian ajaran-ajaranya. Yesus sendiri hadir ke dunia memakai budaya orang Yahudi sehingga pelayananya dapat berhasil. Pemahaman ini tidaklah menjerumuskan kepada praktik sinkretisme. Budaya tidak selalu salah, sebab ada nilai-nilai luhur di dalamnya yang

${ }^{28}$ Wawancara dilakukan pada Jumat, 21 Juni 2019 di Rumah Kepada Desa Samirono, Tawang, dan Latulawang

29 Abdullah Ali, Agama Dalam Ilmu Perbandingan (Bandung: Bandung Nuansa Aulia, 2007). 
tidak bertentangan dengan Firman Tuhan. ${ }^{30}$ Tetapi budaya yang sudah bertentangan dengan ajaran Alkitab serta masuk dalam hal-hal yang berbau kuasa kegelapan, secara sadar dan tegas hal itu harus ditolak.

Pdt. Timotius Turmudi selaku gembala sidang GBI Samirono, bahkan Pdt. Wulandari sebagai gembala sidang gereja Kristen Jawa Tengah Utara (GKJTU) menjelaskan bahwa Sungkeman erat kaitannya dengan Kejawen. Lebih lanjut Pdt. Turmudi menjelaskan bahwa Kejawen adalah pencampuran antara budaya, agama, dan kuasa kegelapan atau kepercayaan kepada animisme dan dinamisme. Ketiganya ini tidak dapat disamaratakan salah dan dibuang. Tetapi ada hal baik yang dapat diambil, salah satunya adalah Sungkeman. Menurut Pdt. Turmudi, budaya Sungkeman harus ada bagi Kekristenan di Jawa. Selain sebagai sarana atau jalan supaya Injil lebih mudah disebarkan kepada orang-orang Jawa, khususnya Desa Samirono dan sekitarnya.

Namun dibalik itu, ada nilai Alkitabiah yang terkandung di dalamnya, yaitu terkait dengan hukum Taurat kelima, "Hormatilah ayahmu dan ibumu, supaya lanjut umurmu di tanah yang diberikan Tuhan, Allahmu, kepadamu." Pdt Turmudi menekankan bahwa orang tua bukan hanya kepada orang tua secara biologis saja, melainkan orang tua rohani yang telah mengajarkan kedewasaan iman selama ini kepadanya. Prinsip ini mesti menjadi nilai yang dipegang secara terus menerus. Oleh karena itu, jika dalam keseharian seorang anak selalu menghormati orang tuanya, dia telah melaksanakan Sungkeman, tanpa perlu menunggu saat lebaran atau pernikahan tiba.

\section{Sorotan Etika Kristen}

Kamus Besar Bahasa Indonesia (KBBI) mendefinisikan etika sebagai nilai ilmu tentang apa yang baik, apa yang buruk, dan tentang hak dan kewajiban moral. ${ }^{31}$ Darmaputra mengungkapkan bahwa etika adalah ilmu atau studi mengenai norma-

30 H. Richard Niebuhr, Christ and Culture (New Yorks: Harper Torchbooks, 1975).

31 Kemendikbud, "Kamus Besar Bahasa Indonesia Daring Edisi Kelima," Badan Pengembangan Dan Pembinaan Bahasa. 
norma yang mengatur tingkah laku manusia, bahwa etika berbicara tentang apa yang seharusnya dilakukan oleh manusia, apa yang benar, baik, dan tepat. ${ }^{32} \mathrm{Hal}$ ini sejalan dengan pernyataan Borrong, bahwa etika adalah ilmu yang mempelajari baik buruk dalam pikiran, perkataan, dan perbuatan manusia. ${ }^{33}$ Kata "etika" berasal dari bahasa Yunani ethos dan ta ethika, yang artinya kebiasaan atau adat. Dalam bahasa Indonesia kata "etika" sepadan dengan kata "kesusilaan", yakni perasaan batin atau kecenderungan hati seseorang melaksanakan suatu perbuatan, serta motif-motifnya dalam melakukan perbuatan tersebut. ${ }^{34}$ Abineno menambahkan bahwa etika dapat diartikan sebagai "tempat tinggal" karena etika berhubungan dengan tempat dimana kita tinggal atau berada. ${ }^{35}$ Signifikansi etika secara umum dan khusus dalam keagaman berhubungan erat dengan budaya bangsa Indonesia yang mengedepankan nilai-nilai kesopanan. Hal ini terlihat jelas dalam budaya Sungkeman dalam hari raya tertentu dan kehidupan sehari-hari. Spirit menghargai seseorang adalah tindakan yang melekat dalam world view masyarakat Desa Samirono.

Menelisik kepada bahasa Latinnya, istilah ethos dan ethikos disebutkan dengan kata "mos", dan "moralitas," oleh sebab itu, kata "etika" sering dijelaskan dengan kata "moral."36 Namun pada kajian ini peneliti harus membedakan etika dengan moral, karena moral adalah berbagai nasihat, wejangan, patokan, kumpulan peraturan, dan ketetapan tentang bagaimana manusia harus hidup dan bertindak baik, hal ini bersumber dari ajaranajaran tradisi, adat istiadat, agama, atau ideologi tertentu. Sedangkan etika bukanlah sebuah ajaran, tetapi sebuah ilmu. Etika adalah pemikiran kritis dan mendasar tentang ajaran serta pandangan moral, sehingga tidak bisa dipahami sebagai sumber

32 Eka Darmaputera, Etika Sederhana Untuk Semua: Perkenalan Pertama (Jakarta: BPK Gunung Mulia, 2015).

33 Robert P. Borrong, Etika Seksual Kontemporer (Bandung: Ink Media, 2006).

${ }^{34}$ J. Verkuyl, Etika Kristen (Jakarta: BPK Gunung Mulia, 2012).

35 J.L.Ch. Abineno, Sekitar Etika Dan Soal-Soal Etis (Jakarta: BPK Gunung Mulia, 1994).

36 Verkuyl, Etika Kristen. 
tambahan bagi ajaran moral saja. ${ }^{37}$ Moral adalah hasil dari nilai etika yang diinternalisasikan dan dilakukan. Sungkeman dalam konteks masyarakat Samirono telah menjadi nilai moral yang telah diajarkan dan dilakukan. Berbagai usaha dilakukan agar nilai moral ini dilakukan, mulai dari pihak gereja yang memasukkan prinsip Sungkeman dalam khotbah-khotbahnya dan sakramen yang dilakukan. Sedangkan dalam tataran masyarakat umum adalah dengan membiasakannya di hari raya besar tertentu.

Sungkeman telah merupakan etika dan telah menjadi etika di Desa Samirono. Etika dalam kehidupan interaksi manusia memiliki banyak manfaat yang dapat memberikan nilai kebersamaan di antara komunitas dan masyarakat yang terlibat. Setidaknya terdapat empat manfaat, yaitu (i) Etika menjadi batasan norma- norma moral, religius, hukum, kesopanan, adat istiadat dan permainan. Disini kita dapat melihat manfaat etika sebagai koridor yang menjadi tuntunan manusia, walaupun bebas dalam berkomunikasi dan berinteraksi tetapi ada rambu-rambu yang harus diikuti; (ii) Etika sebagai norma moral memberikan kesadaran akan tanggung jawab manusia di dalam kebebasannya bertindak. Dengan menjalankan norma moral maka manusia akan dapat bebas berinteraksi sekaligus dapat diterima lingkungannya; (iii) Etika diperlukan karena hukum kadang tidak menjangkau wilayah abu-abu, norma hukum terkadang ketinggalan zaman, sehingga akan terdapat celah-celah hukum, karena hukum sering tidak mampu mendeteksi dampak secara etis tentang kejujuran, keadilan dan prosedur yang wajar terhadap manusia. Contoh yang sekarang menjadi isu panas adalah ujaran kebencian di media sosial ataupun berita hoax; (iv) Etika mengajak orang rasional dalam mengambil keputusan, hal ini dibutuhkan untuk mengarahkan perkembangan masyarakat menuju suasana yang tertib, teratur, damai sejahtera dan saling menghormati. ${ }^{38}$ Dimensi ini yang Rantung sebut sebagai pendidikan

37 Ipel Gunadi, "Konsep Etika Menurut Franz Magnis Suseno" (Fakultas Ushuluddin, 2017).

38 Rokayah, "Penerapan Etika Dan Akhlak Dalam Kehidupan SehariHari," Terampil 2, no. 1 (2015): 15-33. 
Kristen dalam kehidupan majemuk layaknya Indonesia. ${ }^{39}$ Manfaat ini terakomodir dalam budaya Sungkem. Karena itu, melakukan Sungkeman merupakan cerminan dalam menjalankan etika Kristen.

Etika adalah pemikiran sistematis tentang moralitas, yang tidak secara langsung menghasilkan tindakan yang baik dan benar, namun menghasilkan suatu pengertian yang lebih mendasar dan kritis mengenai tindakan yang manusia pilih untuk lakukan, ${ }^{40}$ agar mengerti keuntungan dan kerugian yang terjadi dalam keputusan-keputusan yang dibuat. Lingkungan manusia terus berkembang dan berubah mengikuti ruang dan waktu, hal ini membuat etika menjadi ilmu yang dinamis, karena membicarakan tingkah laku manusia yang berinteraksi dengan perubahan ruang dan waktu. ${ }^{41}$ Suseno menjelaskan bahwa manusia tidak dituntut untuk beretika, tapi manusia dituntut untuk bermoral. ${ }^{42}$ Etika bukanlah sebuah daftar pasti yang mencatat hal-hal yang boleh dilakukan dan tidak dilakukan, malahan etika menggali dan mempertanyakan ilmu-ilmu tersebut, karena seringkali daftar-daftar tersebut hanya bermoralitas tetapi tidak beretika. ${ }^{43}$ Berdasarkan pengertian di atas dapat ditarik kesimpulan bahwa etika adalah ilmu yang mempelajari norma-norma manusia dan digunakan sebagai alat untuk mengetahui mana tindakan, perkataan, dan perbuatan yang benar. Etika juga bersifat dinamis karena sangat dipengaruhi dengan perkembangan lingkungan, adat istiadat, dan kebiasaan.

Etika berkaitan dengan apa yang secara moral benar dan salah, sedangkan Etika Kristen berkaitan dengan apa yang secara moral benar dan salah bagi seorang Kristen. ${ }^{44}$ Jika dilihat dari sudut pandang Hukum Taurat dan Injil, maka Etika Kristen

39 Djoys Anneke Rantung, Pendidikan Agama Kristen Dalam Kehidupan Masyarakat Majemuk (Yogyakarta: Lintang Rasi Aksara Books, 2017).

${ }^{40}$ Gunadi, "Konsep Etika Menurut Franz Magnis Suseno."

${ }^{41}$ Darmaputera, Etika Sederhana Untuk Semua: Perkenalan Pertama.

${ }^{42}$ Gunadi, "Konsep Etika Menurut Franz Magnis Suseno."

${ }^{43}$ Darmaputera, Etika Sederhana Untuk Semua: Perkenalan Pertama.

44 Norman L. Geisler, Etika Kristen: Pilihan \& Isu Kontemporer (Malang: Literatur SAAT, 2015). 
adalah segala hal yang baik yang dikehendaki Allah. Etika Kristen mengutip Alkitab, yang adalah dasar keyakinan orang Kristen pada pernyataan Allah di dalam Kitab Suci. Walaupun Alkitab adalah satu-satunya sumber yang mutlak untuk Etika Kristen, namun bukan berarti Etika Kristen tidak mempunyai alat-alat atau sumber alternatif lainnya. ${ }^{45}$ Brownlee menambahkan bahwa Etika Kristen berusaha untuk membantu manusia berpikir dengan lebih terang tentang kehendak Allah, sehingga dapat mengembangkan dirinya sendiri dan kehidupan masyarakat yang lebih sesuai dengan kehendak Allah. ${ }^{46}$ Bagaimana dengan Sungkeman? Budaya ini tidak bertentangan dengan Alkitab dan etika Kristen. Karena itu, memahami nilai dan melakukan budaya Sungkem merupakan cara untuk orang Kristen mengerti kehendak Tuhan.

\section{Mengasihi Orang Tua dalam Hukum Taurat Ke-5}

Prinsip etika dalam hukum Taurat adalah cerminan dari kehidupan harmonisasi di masyarakat. Luther dan Calvin, bapa gereja Reformator menjelaskan tiga cara mempergunakan hukum Taurat (Triplex usus legis). Pertama, usus elenchticus atau usus paedagogicus yaitu fungsi hukum untuk menginsyafkan akan kesalahan. Kedua, usus normativus atau usus didacticus yang artinya bahwa hukum Taurat memiliki fungsi norma untuk hidup baru dan bersyukur. Ketiga, usu politicus atau usus civilis yang berarti hukum berfungsi sebagai cermin untuk memancarkan keadilan Tuhan di masyarakat dan negara. ${ }^{47}$ Ketiga prinsip ini saling berkaitan untuk menjadikan kehidupan antar sesama manusia menjadi harmonis dan teratur.

Kekristenan memiliki etika dasar yang menjadi pegangan bagaimana seharusnya seseorang berlaku kepada Tuhan dan sesama manusia. Dasar itu adalah 10 hukum Taurat yang terdapat dalam Keluaran 20:3-17 sebagai pristiwa historis pemberian

${ }^{45}$ Verkuyl, Etika Kristen.

${ }^{46}$ Malcom Brownlee, Pengambilan Keputusan Etis Dan Faktor-Faktor Di Dalamnya (Jakarta: BPK Gunung Mulia, 2014).

47 J. Verkuyl, General Section of Christian Ethics [Etika Kristen Bagian Umum], 29th ed. (Jakarta: BPK Gunung Mulia, 2015). 
perintah secara langsung oleh Tuhan kepada Musa. Isi dari Sepuluh perintah adalah perintah dan larangan yang harus dipatuhi oleh orang Israel dalam Perjanjian Lama dan orangorang Kristen dalam Perjanjian Baru hari ini. ${ }^{48}$ Maka, sepuluh perintah selalu relevan dari waktu ke waktu, serta sebagai landasan moral, terutama dalam etika gaya hidup orang Kristen. Namun, dalam praktik penerapan Sepuluh Perintah, ada banyak pemahaman berlebihan, yang menggeser makna sebenarnya. Oleh karena itu, perlu adanya pemahaman Sepuluh Perintah dalam tinjauan Etika Kristen, untuk menghasilkan relevansi dan implementasi yang sesuai dengan makna teologis di dalamnya. ${ }^{49}$ Pembahasan dalam sepuluh hukum Taurat dibagi menjadi dua bagian, pertama adalah perintah yang ditujukan kepada Tuhan (hukum Taurat 1-4), dan kepada sesama (hukum Taurat 5-10). Dalam kajian ini, pembahasan diarahkan kepada bagian kedua karena hukum Taurat ke-5 masuk di dalamnya.

Hukum Taurat ke-5 yang berisi menghormati ayah dan Ibu (Kel. 20:12), diulangi berkali-kali dalam Alkitab yang menunjukkan bahwa perintah ini tidak dibatalkan. Alkitab menunjukkan bahwa Hukum Kelima juga diulangi dalam kitab lain, yaitu dalam Ulangan 5:16, Matius 15:4, 19:19, Markus 7:10, 10:19, Lukas 18:20 dan Efesus 6:2. ${ }^{50}$ Dalam hubungan dengan manusia, dimulai dengan penghormatan kepada orang tua. Tuhan melalui Musa menempatkan menghormati kepada orang tua pada bagian pertama karena dari unit terkecil pembentukan pribadi terjadi yang akan berdampak kepada unit yang lebih luas, yaitu masyarakat atau komunitas tertentu. Dalam keluarga terjadi komunikasi antar individu yang membuat seluruh anggotanya belajar untuk

48 Sarah Andrianti, "Yesus, Taurat Dan Budaya," ANTUSIAS. Jurnal Teologi Dan Pelayanan 2, no. 3 (2013): 1-15, https://www.sttintheos.ac.id/ejournal/index.php/antusias/article/view/51/50.

${ }^{49}$ Christie Kusnandar, "Sepuluh Perintah Tuhan Bagian Kedua: Kasih Terhadap Manusia Dalam Tinjauan Etika Kristen," Jurnal Ilmiah Methonom 3, no. 2 (2017): 73-82.

50 Made Nopen Supriadi, "Interpretasi Hukum Kelima Berdasarkan Pendekatan Sejarah Penebusan," BONAFIDE: Jurnal Teologi Dan Pendidikan Kristen 1, no. 1 (2020): 65-83. 
hidup bersama yang diimplementasikan dengan menempati posisi dan menjalan fungsi sebagaimana mestinya. ${ }^{51}$

Keluaran 20:12 dimulai dengan frasa hormatilah ayah dan ibumu yang berarti tindakan be weighty, be honored, enjoy respect behave with dignity. Secara sederhana adalah hidup yang bersifat santun kepada orang tua. Tindakan ini adalah sebagai bukti nilai tinggi orang. Karena itu Johnson menegaskan bahwa kewajiban menghormati orang tua adalah pantulan (refleksi) seseorang menghormati Tuhan. ${ }^{52}$ Kata wajib perlu ditekankan karena ini bersifat perintah atau hukum, bukanlah opsi yang bisa dilakukan atau tidak. Menarik untuk melihat konteks perintah itu disampaikan. Sepuluh (10) perintah disampaikan kepada Israel yang sedang dalam perjalanan di padang gurun setelah keluar dari perbudakan di Mesir. Orang Israel menganut budaya patriaki, yaitu laki-laki sebagai pribadi yang lebih dihormati daripada wanita. Namun, dalam perintah ke-5 ini tidak dibedakan penghormatan kepada ayah dan ibu. Keduanya dipandang sejajar sebagai orang yang yang harus dihormati. ${ }^{53}$ Hukum taurat ke-5 ini dengan tegas menjadi nilai dalam Sungkeman. Sungkeman yang adalah wujud menghormati orang tua penuh dengan alasan. Bukan hanya karena usia yang lebih tua atau telah melahirkan ke dunia. Melainkan karena kontribusi yang diberikan orang tua dalam mengajarkan nilai hidup dan hikmat yang menyebabkan seorang muda memiliki kemampuan untuk hidup (skill for life).

Frasa selanjutnya "supaya lanjut umurmu di tanah yang diberikan Tuhan, Allahmu, kepadamu" (ay. 12b). Penulis Efesus menyebut perintah ini sebagai "perintah pertama dengan janji" (Ef. 6:2), yaitu dengan janji bahwa Allah memimpin mereka menuju Tanah Perjanjian, jika mereka ingin menikmati masa jabatan mereka di tempat yang diberkati itu untuk waktu yang lama, mereka harus menghormati ayah dan ibu mereka. Dengan

51 Maxie D. Dunnam, Mot Exodus: Mastering the Old Testament (Cleveland, Tennessee: Thomas Nelson Publisher, 1993).

52 Pfeifer and Harrison, The Wycliffe Bible Commentary (Vol. 1) (Malang: Gandum Mas, 2011).

53 James K Bruckner, New International Biblical Commentary: Exodus (Peabody, Massachusetts: Hendrickson Publishers, Inc, 2008). 
demikian, penghormatan terhadap orang tua berkaitan erat dengan masa depan yang berhasil. Hukum Taurat ini adalah janji (futurum). Perintah-janji ini tidaklah berat karena jika kita memandang perintah Tuhan dari latar belakang pekerjaan penyelamatan yang Allah kerjakan (sejarah penyelamatan), maka dapat dikatakan bahwa perintah Tuhan adalah janji juga. ${ }^{54}$ Budaya Sungkem juga merupakan perintah yang juga mengandung janji. Apabila anak melakukan ini, maka doa dan restu dari orang tua akan mengalir dalam keluarga mereka. Restu orang tua ini yang menyebabkan anak berhasil dalam pekerjaan yang dilakukan. Sedangkan dalam Sungkeman idul fitri, maka kerukunan akan memberikan berkat. ${ }^{55}$ Hal ini sejalan dengan firman Tuhan dalam Mazmur 133:1-2.

Perintah ini tidaklah mudah untuk dilakukan oleh anak sebab berkaitan dengan dua siklus kehidupan. Pertama, berkaitan dengan melahirkan dan membesarkan anak, membawa mereka dari ketergantungan mutlak dalam kandungan, menuju kemandirian masa remaja, hingka kedewasaan. Kedua adalah merawat orang tua kita sendiri di tahun-tahun atau usia kemunduran mereka. Seringkali ini melibatkan kemerosotan tubuh fisik, dan pikiran (pikun). Mengasuh anak memang menyakitkan bagi orang tua, tetapi biasanya disertai dengan kegembiraan melihat anak-anak akan tumbuh dewasa, menjadi bertanggung jawab, dan mandiri. Namun berbeda dengan merawat orang tua yang jarang memberikan penghargaan dan puncak dari proses ini adalah kematian. Sungkeman dengan orang tua tidak memberikan kerugian dari berbagai macam aspek. Justru dengan melakukan Sungkeman, hubungan antara anak dan orang tua akan terjalin baik. Sedangkan dalam Sungkeman Idul Fitri, maka hubungan antar masyarakat akan tetap terjaga. Perbedaan pendapat dan gesekan yang terjadi

\section{Umum]}

${ }^{54}$ Verkuyl, General Section of Christian Ethics [Etika Kristen Bagian

${ }^{55}$ Anugerah Ayu Sendari, "Tradisi Sungkem Saat Lebaran Dan Maknanya, Bagian Budaya Indonesia," Liputan 6 News, last modified 2021, accessed December 20, 2021, https://hot.liputan6.com/read/4548936/tradisisungkem-saat-lebaran-dan-maknanya-bagian-budaya-indonesia\#: :text= Sungkeman adalah sebuah prosesi adat,untuk meminta restu orang tua. 
akibat interaksi sosial yang terjadi dapat diatasi dengan kekeluargaan.

Generasi muda, terkhusus generasi $\mathrm{Z}$ yang lahir tahun 1995-2010 identik dengan kehidupan yang pragmatis-realistis. Karakteristik ini melekat dengan mereka karena kehidupan mereka yang lahir dalam penderitaan, terkhusus di Indonesia. Mereka merasakan keadaan genting Indonesia tahun 1998 dan mereka juga merasakan pandemi covid-19 yang tidak kunjung selesai. ${ }^{56}$ Penelitian yang dilakukan oleh David dan Jonah Stillman juga menunjukkan bahwa Gen-Z adalah pribadi yang begitu realistis karena peristiwa seperti resesi, terorisme, volatilitas, kekacauan, dan ketidakpastian menjadi suatu konteks Gen-Z tumbuh. ${ }^{57}$ Inilah yang kemudian dijelaskan oleh James Emery White bahwa Gen-Z memiliki keinginan yang sangat kuat untuk membuat suatu perbedaan bagi dunia mereka. Hal ini menjadi suatu cara Gen-Z untuk mengatasi suatu konteks dunia yang begitu tidak pasti. ${ }^{58}$ Mereka juga pribadi yang hidup dalam keberagaman moral dan culture karena kecanggihan teknologi yang membuat arus globalisasi berjalan dengan massif menggantikan nilai-nilai khas daerah (kearifan lokal) yang selama ini dijaga. Postmodern dengan pluralisme dan relativisme ${ }^{59}$ juga meresap dalam pikiran dan spiritualitas mereka. Keterbukaan ini dikhawatirkan dapat menghilangkan prinsip, nilai dan praktik budaya Sungkem.

56 Aldi Abdillah and Anggi Maringan Hasiholan, "Beri Aku Air Hidup, Tuhan!': Seru Perempuan Samaria Dan Gen-Z (Suatu Tafsir Kontrapuntal Yohanes 4:14 Sebagai Laku Spiritualitas Generasi Z Indonesia Era Postmodern)," Jurnal Abdiel: Khazanah Pemikiran Teologi, Pendidikan Agama Kristen dan Musik Gereja 5, no. 2 (2021): 176-191.

57 David Stillman and Jonah Stillman, Generasi Z: Memahami Karakter Generasi Baru Yang Akan Mengubah Dunia Kerja (Jakarta: Gramedia Pustama Utama, 2019).

58 James Emery White, Meet Generation Z: Understand and Reaching the New Post-Christian WOrld (Michigan: Baker Books, 2017).

59 Tambunan and Setyobekti, "Ekstraksi Pemahaman Cyprianus Tentang Extra Ecclesiam Nulla Salus Bagi Gereja Pentakosta Di Era Postmodern." 
Menghadapi realita ini, gereja dan masyarakat mesti melakukan internalisasi nilai-nilai menghormati orang tua kepada anak muda dengan cara yang berbeda. Pandemi memang telah menjarakkan antar manusia, namun pandemi Covid-19 tidak bisa melunturkan nilai saling menghormati dalam kehidupan masyarakat. Gadget dapat menjadi sarana pembelajaran ${ }^{60}$ nilai etika kristen dan hukum Taurat ke-5 untuk Sungkem terhadap orang lain. Memang secara praktik dalam pernikahan dan Idul Fitri perlu direaktualisasi kembali, namun nilai-nilai yang telah penulis jelaskan di atas tidak dapat dikurangi sedikitpun. Generasi muda dengan pragmatisnya mesti memandang lingkungan dan komunitas masyarakatnya sebagai wadah implementasi hukum Taurat ke-5. Artikel ini mengusulkan karena realitas dalam generasi muda Desa Samirono yang menjalankan Sungkem hanya sebagai ritual, bukan nilai-nilai luhur yang harus dilestarikan. Dalam tataran agama, nilai dan praktik Sungkem dapat menjadi pembahasan inkulturasi liturgi gereja. Anak muda di Desa Samirono perlu menjaga kearifan lokal melalui budaya sungkem sebagai basis penguatan nilai religi.

\section{PENUTUP}

Di zaman yang sarat dengan kebebasan dan kesejajaran, seharusnya budaya Sungkem menjadi tindakan yang dilakukan oleh anak-anak muda Kristen secara konsisten. Mungkin tidak dalam konteks meminta restu atau meminta maaf, melainkan sebagai cara meninggikan derajat orang tua yang telah membesarkan dan mendidik. Hal ini penulis sampaikan karena dengan berkembangnya teknologi dan informasi yang pesat sehingga pengetahuan mudah didapat, anak-anak muda akan merasa lebih pintar dan mengerti akan segala sesuatu daripada orang tuanya. Dampak kedepannya adalah rasa superioritas terhadap orang tua. Oleh karena itu, dengan melaksanakan Sungkem setiap hari,

60 Anggi Maringan Hasiholan and Yehezkiel V Fernando, "Manfaat Penggunaan Gadget Terhadap Minat Belajar Siswa Pendidikan Kristen Pada Era Postmodern," Edukatif: Jurnal Ilmu Pendidikan 3, no. 4 (2021): 24012410 . 
generasi muda diingatkan untuk terus menundukkan diri terhadap orang tua walaupun pengetahuan dan jabatannya dalam pekerjaan lebih tinggi daripada orang tuanya.

Menghormati orang tua dari budaya Sungkem merefleksikan hukum Taurat ke-5 dan etika Kristen. Sungkeman memiliki nilai luhur yang tidak bertentangan dengan Kekristenan secara dogma dan spiritualitas. Tindakan Sungkem sejajar dengan bagaimana orang Yahudi memenuhi kebutuhan orangtua (Mat. 15:3-6). Kesejajaran ini karena nilai memelihara orangtua yang terkandung juga dalam Sungkeman. Hal ini ditekankan oleh Yesus juga ketika di kayu Salib Dia meminta agar muridnya yang bernama Yohanes untuk memelihara ibunya. Dengan demikian nyatalah bahwa memelihara orang tua merupakan perintah penting. Dalam etika Kristen, menghormati orangtua harus dilakukan tanpa memandang bagaimana sikap dan kontribusi orangtua. Tetapi dalam mematuhi orangtua, terdapat batasan yang harus dilakukan, yaitu apabila perintahnya sesuai atau tidak dengan Firman Tuhan. Pada kajian ini, Sungkeman tidak bertentangan dengan Firman Tuhan.

Nilai Sungkeman yang merupakan implementasi dari hukum taurat ke-5 dan etika Kristen sudah seharusnya menjadi pokok ajaran dalam gereja bagi generasi muda, khususnya di Desa Samirono. Penguatan nilai ini dapat dilakukan dengan pemuridan yang memadukan antara pengajaran dan perjumpaan. Pengajaran dilakukan dalam ibadah pemuda (youth) pada hari Sabtu, dan ibadah kelompok sel di rumah-rumah. Sedangkan dimensi perjumpaan dapat dilakukan dengan praktik langsung kepada orangtua dalam gereja setelah ibadah, dan pendeta yang telah mengajarkan kebenaran Firman Tuhan. Dengan penguatan nilai religius, maka nilai bahkan praktik Sungkeman di Desa Samirono akan terjaga.

\section{Ucapan Terima Kasih}

Peneliti mengucapkan terima kasih kepada Ketua Prodi STT Bethel Indonesia, Ivonne Sandra Sumual yang telah memfasilitasi penelitian ini secara langsung untuk bertemu dengan masyarakat dan para pemimpin Desa Samirono. Tim peneliti 
juga berterima kasih kepada masyarakat Desa Samirono yang memberikan kesempatan bagi tim untuk tinggal di rumah-rumah masyarakat, secara khusus Ibu Mukiem yang mewakili bapak Kepala Desa Samirono atas sambutan dan informasinya terkait demografi dan keadaan masyarakat Desa Samirono.

\section{DAFTAR PUSTAKA}

Abdillah, Aldi, and Anggi Maringan Hasiholan. "'Beri Aku Air Hidup, Tuhan!': Seru Perempuan Samaria Dan Gen-Z (Suatu Tafsir Kontrapuntal Yohanes 4:14 Sebagai Laku Spiritualitas Generasi Z Indonesia Era Postmodern)." Jurnal Abdiel: Khazanah Pemikiran Teologi, Pendidikan Agama Kristen dan Musik Gereja 5, no. 2 (2021): 176-191.

Abineno, J.L.Ch. Sekitar Etika Dan Soal-Soal Etis. Jakarta: BPK Gunung Mulia, 1994.

Ali, Abdullah. Agama Dalam Ilmu Perbandingan. Bandung: Bandung Nuansa Aulia, 2007.

Andrianti, Sarah. "Yesus, Taurat Dan Budaya." ANTUSIAS. Jurnal Teologi Dan Pelayanan 2, no. 3 (2013): 1-15. https://www. sttintheos.ac.id/e-journal/index.php/antusias/article/view/51/50.

Andy, Safria. "Hakikat Puasa Ramadhan Dalam Perspektif Tasawuf (Tafsir Q.S Al-Baqarah: 183).” Jurnal Ibn Abbas (2017): 1-17.

Arif, Muh, and Yandu Lasantu Melki. "Nilai Pendidikan Dalam Tradisi Lebaran Ketupat Masyarakat Suku Jawa Tondano Di Gorontalo." Madani 1, no. 2 (2019): 144-159.

Ariyanto, M. Darojat, Abdullah Mahmud, and Tri Yuliana Wijayanti. "Konsep Puasa Dalam Agama Protestan." Suhuf 24, no. 1 (2012): 99-119. https://publikasiilmiah.ums.ac.id/bitstream/ handle/11617/3085/2. DAROJAT ARIYANTO.pdf? sequence= $1 \&$ isAllowed=y.

Bahri, Saiful. "Implementasi Pendidikan Karakter Dalam Mengatasi Krisis Moral Di." Jurnal Pendidikan Karakter 03, no. 01 (2015): 57-76.https://media.neliti.com/media/publications/67939-ID-implementasi-pendidikan-karakter-dalam-m.pdf. 
BUDAYA SUNGKEM DESA SAMIRONO DALAM PERSPEKTIF HUKUM

TAURAT KE-5: SUATU KAJIAN ETIKA KRISTEN DAN GENERASI MUDA - Gernaida Pakpahan, dkk.

Borrong, Robert P. Etika Seksual Kontemporer. Bandung: Ink Media, 2006.

Brownlee, Malcom. Pengambilan Keputusan Etis Dan Faktor-Faktor Di Dalamnya. Jakarta: BPK Gunung Mulia, 2014.

Bruckner, James K. New International Biblical Commentary: Exodus. Peabody, Massachusetts: Hendrickson Publishers, Inc, 2008.

Christie Kusnandar. "Sepuluh Perintah Tuhan Bagian Kedua: Kasih Terhadap Manusia Dalam Tinjauan Etika Kristen." Jurnal Ilmiah Methonom 3, no. 2 (2017): 73-82.

Darmaputera, Eka. Etika Sederhana Untuk Semua: Perkenalan Pertama. Jakarta: BPK Gunung Mulia, 2015.

Dewantoro, Ki Hajar. Bagian II A: Kebudayaan. Yogyakarta: Madjelis Luhur Persatuan Taman Siswa, 1967.

Dunnam, Maxie D. MOT EXODUS: Mastering the Old Testament. Cleveland, Tennessee: Thomas Nelson Publisher, 1993.

Fathoni, Adib. "Santri Dan Abangan Dalam Kehidupan Keagamaan Orang Jawa." Jurnal At-Taqaddum 4, no. 1 (2012): 101-112.

Francis, Tracy, and Fernanda Hoefel. "True Gen": Generation $Z$ and Its Implications for Companies. McKinsey \& Company, 2018.

Geertz, C. Tafsir Kebudayaan. Yogyakarta: Kanisius, 2000.

Geisler, Norman L. Etika Kristen: Pilihan \& Isu Kontemporer. Malang: Literatur SAAT, 2015.

Gunadi, Ipel. "Konsep Etika Menurut Franz Magnis Suseno.” Fakultas Ushuluddin, 2017.

Hasiholan, Anggi Maringan, and Yehezkiel V Fernando. "Manfaat Penggunaan Gadget Terhadap Minat Belajar Siswa Pendidikan Kristen Pada Era Postmodern." Edukatif: Jurnal Ilmu Pendidikan 3, no. 4 (2021): 2401-2410.

Indrati, Septin Lovenia. "Philosophical Values and Local Wisdom in Java Panggih Traditional Ceremony Language." PAROLE: Journal of Linguistics and Education 7, no. 2 (2018): 93.

Kemendikbud. "Kamus Besar Bahasa Indonesia Daring Edisi Kelima." Badan Pengembangan Dan Pembinaan Bahasa. 
Koentjaraningrat. Sejarah Teori Antropologi I. Jakarta: Universitas Indonesia Press, 1987.

Muhammad, Arif. "Sungkeman, Aktivitas Wajib Di Hari Lebaran, Warisan Budaya Bangsa Sarat Makna." Kompasiana.

Niebuhr, H. Richard. Christ and Culture. New Yorks: Harper Torchbooks, 1975.

Oktafia, Lailatul Hanik Wahyu. "KAJIAN ETNOGRAFI TRADISI SUNGKEM TROMPAK DI DESA POGALAN KABUPATEN MAGELANG (Kearifan Lokal Dan Konservasi Lingkungan)." Universitas Islam Negeri Walisongo Semarang, 2018.

Patilima, Hamid. Metode Penelitian Kualitatif. 6th ed. Bandung: Alfabeta, 2016.

Permatasari, Afika Fitria, and Mahendra Wijaya. "Perubahan Perilaku Masyarakat Jawa Dalam Penyelenggaraan Resepsi Pernikahan Di Kota Surakarta." Jurnal Analisa Sosiologi 6, no. 1 (2018): 65-81.

Pfeifer, and Harrison. The Wycliffe Bible Commentary (Vol. 1). Malang: Gandum Mas, 2011.

Pringgawidagda, Suwarna. Tata Upacara Dan Wicara Pengantin Gaya Yogyakarta. Yogyakarta: Kanisius, 2011.

Qudus, Achmad Zubair Abdul. "Kemanten Jadur (Studi Etnografi Tentang Makna Simbolik Dalam Prosesi Perkawinan Di Kelurahan Lumpur, Kecamatan Gresik, Kabupaten Gresik).” AntroUnairdotNet 2, no. 1 (2013): 134-144.

Rantung, Djoys Anneke. Pendidikan Agama Kristen Dalam Kehidupan Masyarakat Majemuk. Yogyakarta: Lintang Rasi Aksara Books, 2017.

Rohman, Fatkhur. "Makna Filosofi Tradisi Upacara Perkawinan Adat Jawa Kraton Surakarta Dan Yogyakarta (Studi Komparasi)." Universitas Negeri Islam Walisongo, 2015.

Rokayah. "Penerapan Etika Dan Akhlak Dalam Kehidupan SehariHari." Terampil 2, no. 1 (2015): 15-33.

Semarang, Pemerintah Daerah Kabupaten. "DESA SAMIRONO." Pemerintah Daerah Kabupaten Semarang. Last modified 2019. Accessed January 17, 2021. https://getasan.semarangkab. go.id/ 
BUDAYA SUNGKEM DESA SAMIRONO DALAM PERSPEKTIF HUKUM TAURAT KE-5: SUATU KAJIAN ETIKA KRISTEN DAN GENERASI MUDA - Gernaida Pakpahan, dkk.

desa-samirono/.

Sendari, Anugerah Ayu. "Tradisi Sungkem Saat Lebaran Dan Maknannya, Bagian Budaya Indonesia." Liputan 6 News. Last modified 2021. Accessed December 20, 2021. https://hot.liputan6. com/ read/4548936/tradisi-sungkem-saat-lebaran-dan-maknanyabagian-budaya-indonesia\#: :text=Sungkeman adalah sebuah prosesi adat,untuk meminta restu orang tua.

Soesilo, and Krisnina Maharani Tandjung. Kejawen: Philosofi Dan Perilaku. 4th ed. Malang: Yayasan Yusula, 2005.

Stillman, David, and Jonah Stillman. Generasi Z: Memahami Karakter Generasi Baru Yang Akan Mengubah Dunia Kerja. Jakarta: Gramedia Pustama Utama, 2019.

Sugiyono. Metode Penelitian Kualitatif Dan $R$ and D. Bandung: Alfabeta. Alfabeta, 2015.

Supriadi, Made Nopen. "INTERPRETASI HUKUM KELIMA BERDASARKAN PENDEKATAN SEJARAH PENEBUSAN." BONAFIDE: Jurnal Teologi dan Pendidikan Kristen 1, no. 1 (2020): 65-83.

Tambunan, A M Hasiholan, and Andreas Budi Setyobekti. "Ekstraksi Pemahaman Cyprianus Tentang Extra Ecclesiam Nulla Salus Bagi Gereja Pentakosta Di Era Postmodern." KHARISMATA: Jurnal Teologi Pantekosta 4, no. 1 (2021): 28-42.

Verkuyl, J. Etika Kristen. Jakarta: BPK Gunung Mulia, 2012.

- General Section of Christian Ethics [Etika Kristen Bagian Umum]. 29th ed. Jakarta: BPK Gunung Mulia, 2015.

White, James Emery. Meet Generation Z: Understand and Reaching the New Post-Christian WOrld. Michigan: Baker Books, 2017. 


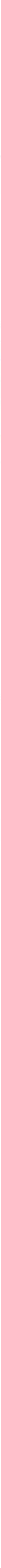

